\title{
Serum cholesterol levels in relation to the serum albumin in first episode of idiopathic nephrotic syndrome of childhood.
}

\author{
Dr. Bharat Reddy ${ }^{1}$, Dr. Venkataramana Reddy ${ }^{2}$, Dr. Chapay Soren ${ }^{3}$, \\ Junior Resident ${ }^{1}$, Assistant Professor ${ }^{2}$, Professor \& Head Of The Department ${ }^{3}$, \\ Department Of Pediatrics, SVS Medical College \& Hospital. Mahabubnagar, Telangana
}

\begin{abstract}
Aims and Objectives: The aim of this study was to evaluate the direct relationship between serum cholesterol and serum albumin in first episode of idiopathic nephrotic syndrome of childhood.

Methods and materials: A prospective observational study included 28 children with nephrotic syndrome, aged between of 2-8 years with 14 age and sex matched controls were studied at SVS Medical College and Hospital, Mahabubnagar during period of July 2015 to December 2016.

Results and discussion: The mean albumin was $1.81 \mathrm{~g} / \mathrm{dL}$, mean serum proteins were $4.41 \mathrm{~g} / \mathrm{dL}$ and mean serum cholesterol level was $459.30 \mathrm{mg} / \mathrm{dL}$.A negative correlation between serum albumin and serum cholesterol levels $(r=-0.850)$ in our study, which was statistically significant $(p<0.000)$.

Conclusion: This study showed that lower the serum albumin level, higher will be cholesterol level. There is a negative correlation between serum cholesterol level and serum albumin level in childhood nephrotic syndrome.

Keywords: Nephrotic Syndrome, serum cholesterol, serum albumin.

\section{Introduction}

Nephrotic syndrome is a kidney disease characterized by heavy proteinuria, hypoalbuminemia, hyperlipidemia and oedema. The cumulative prevalence rate is approximately 15.5 cases per $100,000^{1}$. The pathogenesis of nephrotic syndrome is still not clear. The alterations in the integrity of the glomerular filtration barrier with effacement of podocytes is suggested to be the cause for proteinuria ${ }^{2,3}$. The increased lipoprotein synthesis occurs due to undefined mechanisms related to hypoalbuminemia. Increased synthesis as well as decrease in clearance of lipoprotein may contribute to the hyperlipoproteinemia ${ }^{4}$.
\end{abstract}

\section{Aims}

To evaluate the direct relationship between serum cholesterol and serum albumin in first episode of childhood nephrotic syndrome.

\section{Patients and Methods}

Patients in the age group of 2-8 years with typical clinical features of nephrotic syndrome that are admitted to SVS Medical College and Hospital, Mahabubnagar, between July 2015 to December 2016 are included in the study. The children less than 2 years and greater than 8 years and children with liver disease, kidney diseases other than nephrotic syndrome, protein energy malnutrition, congestive heart failure, relapse cases of nephrotic syndrome and family history of hypercholesterolemia were excluded.

Written consent was obtained from parent prior to enrolment and the study was approved by institutional ethical committee.

\section{Data collection}

Data was collected by using pre-tested proforma meeting the objectives of the study. Nephrotic syndrome was diagnosed based on presence of peri-orbital puffiness, spot urinary protein creatinine ratio of $>2.0$, hypoalbuminemia $(<2.5 \mathrm{mg} / \mathrm{dL})$, and hypercholesterolemia $(>200 \mathrm{mg} / \mathrm{dL})$. Method used for estimation of serum cholesterol is CHOD POD and for serum albumin, Bromo cresol green. Fourteen children who were agematched and without liver and kidney disorders were taken as control group.

\section{Data Analysis And Interpretation}

Statistical Analysis: Data was analyzed by Graph Pad Prism software (version 6.0). Data was described by Mean \pm SD for continuous normal data and data was described by percentages for categorical data. The comparison between two groups for continuous normal data was done by unpaired t-test/ for continuous non-normal data was done by Mann Whitney test or Wilcoxon Rank Sum test. The relation between two 
variables for continuous normal data was done by Karl Pearson's correlation coefficient test/ for continuous non-normal data was done by Spearman's rank correlation coefficient test. The comparison between three groups for continuous normal data was done by "One-way analysis of variance test" and followed by Bonferroni's Multiple Comparison test. All p-values less than 0.05 were considered as statistically significant.

\section{Results}

Table No 1: Sex distribution of studied population

\begin{tabular}{|l|l|}
\hline SEX & NO. OF PATIENTS(PERCENTAGE) \\
\hline MALE & $16(57)$ \\
\hline FEMALE & $12(43)$ \\
\hline
\end{tabular}

Among the 28 children studied, 16 were males (57\%) and 12 were females (43\%). Male preponderance was seen in our study $(\mathrm{n}=28,57 \%$ male), which is in concordance with Srineevasa. $\mathrm{B}$ et al $(\mathrm{n}=50$, $60 \%$ male $)^{5}$.

Table-2: The comparison between controls and cases for the parameters Age (in years), Serum Albumin, Serum Proteins, Serum Cholesterol

\begin{tabular}{|l|l|l|l|l|l|l|}
\hline Parameter & Groups & $\mathrm{n}$ & Range & Mean & SD & P-Value \\
\hline \multirow{2}{*}{ Age (in years) } & Controls & 14 & 2 to 8 & 5.14 & 1.83 & \multirow{2}{*}{0.902} \\
\cline { 2 - 7 } & Cases & 28 & 2 to 8 & 5.07 & 1.72 & \\
\hline \multirow{2}{*}{ Serum Albumin } & Controls & 14 & 3.5 to 4.5 & 4.04 & 0.32 & \multirow{2}{*}{$\mathbf{0 . 0 0 0}$} \\
\cline { 2 - 7 } & Cases & 28 & 1.2 to 2.4 & 1.81 & 0.39 & \\
\hline \multirow{2}{*}{ Serum Proteins } & Controls & 14 & 6.5 to 7.7 & 7.13 & 0.40 & \multirow{2}{*}{$\mathbf{0 . 0 0 0}$} \\
\cline { 2 - 7 } & Cases & 28 & 3.5 to 5.2 & 4.14 & 0.54 & \\
\hline \multirow{2}{*}{ Serum Cholesterol } & Controls & 14 & 154 to 197 & 173.50 & 12.46 & \multirow{2}{*}{$\mathbf{0 . 0 0 0}$} \\
\cline { 2 - 6 } & Cases & 28 & 289.4 to 650.1 & 459.30 & 106.90 & \\
\hline
\end{tabular}

Among the study population, the mean albumin was $1.81 \mathrm{~g} / \mathrm{dL}$, mean serum protein was $4.41 \mathrm{~g} / \mathrm{dL}$ and mean serum cholesterol level was $459.30 \mathrm{mg} / \mathrm{dL}$. The difference between serum albumin, proteins, and cholesterol levels in nephrotic syndrome patients compared to controls is a statistically significant ( $p$ value $=0.000$ ). Similar finding was observed by Srineevasa. B et al ( $\mathrm{p}$ value less than 0.005$)^{5}$.

Table-3: The correlation between the Serum Albumin and Serum Cholesterol

\begin{tabular}{|l|l|l|l|l|l|l|}
\hline Parameters & $\mathbf{n}$ & Range & Mean & SD & r-value & P-value \\
\cline { 1 - 5 } Serum Albumin & 28 & 1.2 to 2.4 & 1.81 & 0.39 & -0.850 & 0.000 \\
\hline Serum Cholesterol & 28 & 289.4 to 650.1 & 459.30 & 106.90 & & \\
\hline
\end{tabular}

Our study showed a significant negative correlation between serum albumin and serum cholesterol levels $(\mathrm{r}=-0.850$ and $\mathrm{p}$-value 0.000$)(\mathrm{n}=28)$. Similar findings were found in studies conducted by Hossain. MA et al $(\mathrm{n}=60)^{6}$ and Srineevasa. B et al. $(\mathrm{n}=50)^{5}$.

Figure-1: The scatter plot between the parameters Serum Albumin and Serum Cholesterol

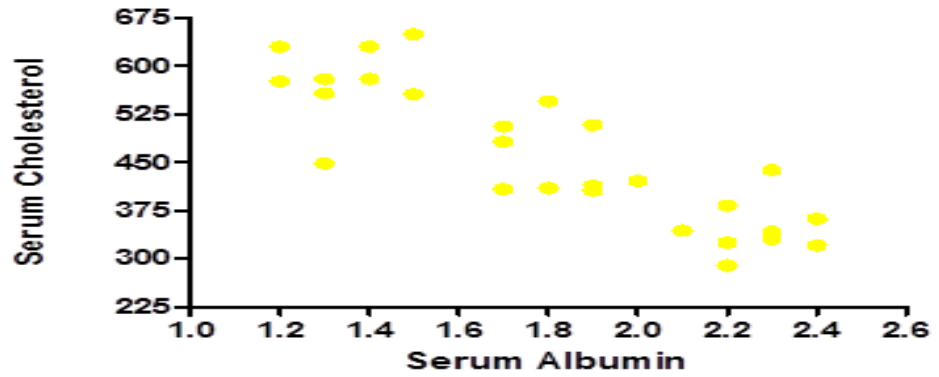

Table-4: The comparison between Serum Albumin levels for the parameter Serum Cholesterol

\begin{tabular}{|l|l|l|l|l|l|}
\hline Serum Albumin & $\boldsymbol{n}$ & Range & Mean & SD & P-Value \\
\hline 1 to 1.5 & 9 & 448.8 to 650.1 & 579.1 & 59.40 & \multirow{2}{*}{ 1.6 to 2} \\
\hline 2.1 to 2.5 & 10 & 406.3 to 545.4 & 451.4 & 53.28 & \multirow{0}{*}{.000 } \\
\hline
\end{tabular}


Inverse correlation was seen between serum albumin and serum cholesterol levels, which is statistically significant $(\mathrm{p}$ value $=0.000)$. Dyanesh. DK et al $(n=30)^{7}$ and Beck. $\mathrm{P}$ et al $(\mathrm{n}=30)^{8}$, also showed that there was a negative correlation between serum albumin and serum cholesterol levels, but their results were not statistically significant.

Figure-2: The mean bar graph for the comparison between Serum Albumin levels and Serum Cholesterol



\section{Discussion}

Idiopathic nephrotic syndrome is a common renal disease among children. The common age group is 2-6 years and boys are affected more than girls. Onset is insidious. Most children present with periorbital puffiness and anasarca. Altered permeability in the glomerular basement membrane due to $\mathrm{T}$ cell mediated molecular mimicry, that leads to loss of macromolecules in the urine which are normally retained from the ultrafiltrate. This results in heavy proteinuria, albuminemia and edema. There occurs increased synthesis of lipoproteins from liver resulting in hypercholesterolemia. All patients in our study had a relatively high value of serum total cholesterol (mean of $459.3 \mathrm{mg} / \mathrm{dl}$ ) and low value of serum total albumin values (mean of 1.81 $\mathrm{mg} / \mathrm{dl})$. We have observed a negative correlation $(\mathrm{r}=-0.85$ and a $\mathrm{p}$ value- 0.000$)$ between serum albumin and serum cholesterol. A statistically significant Inverse correlation between serum albumin and serum cholesterol has been found in studies conducted by Srineevasa.B et al $(n=30)^{5}$, and Hossain. MA et al $(n=60)^{6}$. The result of our study has shown similar findings like above studies. Dyanesh. DK et al $(n=30)^{7}$, Beck. P et al $(n=30)^{8}$ and Krishnaswamy D et al $(n=20)^{9}$ also found negative correlation between serum albumin and serum cholesterol, but it was statistically not significant.

\section{Conclusion}

There is a negative correlation between serum cholesterol level and serum albumin level in childhood nephrotic syndrome. This study showed that lower the serum albumin level, higher will be the serum cholesterol level. Further studies are necessary, because of the small sample size.

\section{References}

[1]. Safaei A, Maleknejad S. Spectrum of childhood nephrotic syndrome in Iran: A single center study. Indian J Nephrol. 2009 Jul;19(3):87-90. doi: 10.4103/0971-4065.57103.

[2]. Certikova-Chabova V, Tesar V. Recent insights into the pathogenesis of nephrotic syndrome. Minerva Med. 2013 Jun;104(3):33347.

[3]. RAHMAN, MH; JESMIN, T; MUINUDDIN, G. An Update of Management of Idiopathic Nephrotic Syndrome: A Review Article. Bangladesh Journal of Child Health, [S.1.], v. 37, n. 2, p. 102-121, dec. 2013. ISSN 2408-8315. Available at: <http://www.banglajol.info/index.php/BJCH/article/view/17268>. Date accessed: 30 Sep. 2016. doi:http://dx.doi.org/10.3329/bjch.v37i2.17268.

[4]. Attman PO, Alaupovic P. Pathogenesis of hyperlipidemia in the nephritic syndrome. Am J Nephrol. 1990;10 Suppl 1:69-75.

[5]. B. Sreenivasa, Kumar P, S. Babu M.T, S. K. Ragavendra. Serum Lipid profiles during onset and remission of steroid sensitive Nephrotic Syndrome in Children. BMR Medicine. 2015;1(1), pp.1-4 
[6]. Hossain MA, Deb KP, Mannan KA, Mostafa G et al. Correlation between Serum Cholesterol and Serum Albumin Level in Childhood Nephrotic Syndrome. Urol Nephrol Open Access J. 2016;3(4): 00086. DOI: 10.15406/unoaj.2016.03.00086

[7]. Dnyanesh DK, Dnyanesh S, Shenoy V. A study of serum lipids in nephrotic syndrome in children. IOSR-JDMS. 2014;13(3):0106.7

[8]. Beck P, Kurrey VK, Dawale P. To study lipid profile and its correlation with serum albumin level in Nephrotic Syndrome in children. Indian Journal of Applied Research. 2015;10(5): 329-330.

[9]. Krishnaswamy D, Indumati V, Sathishkumar D, Vijay V, Maharudra.Shekanawar, Amareshwara.Maligi et al. Serum proteins, initial and follow up lipid profile in children with nephrotic syndrome. International journal of Applied Biology and pharmaceutical technology. 2011;2(3):59-64. 